\title{
EXPERIENCE IN IMPLEMENTING RESOURCE-BASED LEARNING IN AGRARIAN COLLEGE OF MANAGEMENT AND LAW POLTAVA STATE AGRARIAN ACADEMY
}

\author{
Natalia KONONETS \\ Agrarian College of Management and Law \\ Poltava State Agrarian Academy \\ Poltava, UKRAINE
}

\section{ABSTRACT}

The introduction of resource-based learning disciplines of computer cycles in Agrarian College. The article focused on the issue of implementation of resource-based learning courses in the agricultural cycle computer college. Tested approach to creating elearning resources through free hosting and their further use in the classroom. Noted that the use of Internet technology makes it possible to create educational environment Agrarian College is through the development and deployment of electronic educational resources on the Web, because the Internet is constantly expanding its capabilities, services, hosted with them information that is relevant in terms of education.

The author proposes to consider e-learning resource "Інформатика+="Information+": http://informatika-resurs.jimdo.com which combines the characteristics and principles of creation of electronic media for educational purposes and is a modern didactic resource for the study of the disciplines of computer cycle. Demonstrates Cloud resources from the disciplines of computer cycle, e-learning content "IT-education", developed with the help of Google services for online learning. Cloud resource is a collection of electronic teaching systems such disciplines of "Computer Science and Computer Engineering", "E-commerce", "Data Protection", "Computer technologies in legal activity". The study is focused on free hosting for the development of electronic learning resources (Jimdo, uCoz), which enable the creation of a site (does not require special skills and knowledge of programming languages), fast and, most importantly, free of charge, which is particularly important given the current financial support of agricultural colleges.

Keywords: Resource-based learning, e-learning resources, information and educational environment, Agrarian College.

\section{INTRODUCTION}

European Commission in the plan of businesses on questions electronic education defined essence of European educational space as use of new hypermedia technologies and Internet technologies for the improvement of quality of studies, facilitating access to the resources and services, and also remote exchange and collaboration. Confession of electronic education became a next step by the necessary attribute of Bolonsky of process (Bologna, 2004). 
In this context passing to the resource-based learning (RBL), which is sent to the use of pedagogical innovations and modern of informatively-communication technologies (ICT), active bringing in to the pedagogical process of librarians and it is oriented to education during all life, is logical and actual (Kononets, 2012).

A large role in the educational process of modern agrarian college at RBL of students is played by the task of creation and introduction of the integrated educational environment, the basic purpose of which is a high-quality change of process of teaching of base and special disciplines and control of knowledge. Informative educational space is computer-integrated as didactics basis of RBL will allow to activate the process of creation of scientific and educational informative resources of college, extend possibilities of studies, giving practical skills of work in a hi-tech environment, to promote qualification of teachers in area of the practical use of IKT in an educational process.

Introduction of RBL of disciplines of computer cycle in the environment of students of the Agrarian College of Management and Law Poltava State Agrarian Academy actualized a requirement in creation of electronic educational resources for the use their students in the process of studies and self-education.

\section{ANALYSIS OF THE LAST RESEARCHES}

The system RBL and problems of its introduction in practice of studies of students of institute of higher are investigated by the foreign scientists of Abdul Paliwala, Margaret Butler, Elizabeth Green, Janet Macdonald, Janette R. Hill, Michael J. Hannafin, Jacqueline Smith-Autard, Said Hadjerrouit, Paul Maharg, Christine Greenhow, Sara Dexter, Dale Holt, Christine Armatas, Mary Rice. Development, creation and introduction of electronic tools of studies actively engage in A. Bashmakov, M. Belyaev, V. Bykov, V. Vul, A. Hrechihin, V. Gura, V. Demkin, A. Derevnina, M. Zhaldak, P. Zalmanov, L. Zaynutdinova, A. Spivakovsky and many other foreign and home scientists which simply determine a necessity and actuality of the use of these tools for an educational process.

Said Hadjerrouit (Norway), investigating tools, forms and methods of RBL, suggests to carry out the web-oriented studies potential of which is so large, as far as rich in educational resources the World wide web. The methods of realization of such studies foresee the study of web-bases of virtual studies, methodology technologically-oriented or on-line studies, use of electronic Internet resources and development of own educational web-resources (Hadjerrouit, 2005, Hadjerrouit, 2010). In the process of research of didactics possibilities of services of the Internet and on-line studies, Dale Holt, Christine Armatas, Mary Rice (Australia) mark, that the systematic use of resources and query of the Global network facilities assists a grant to the results of studies of practical orientation, promotes the level of informative culture of students, and also logical and critical thought (Holt et al., 2002). Under RBL understand the complex of forms, methods and tools of studies, aimed at the integral going near organization of educational process, which is orientated not only on mastering of knowledge and acquisition of skills but also on training of capabilities of independent and active transformation of informative environment by a search and practical application of informative resources (Kononets, 2012). 


\section{AIM OF THE STUDY}

Aim of the article - to present experience of introduction of the resource-based learning of students at the study of disciplines of computer cycle the tools of electronic educational resources in the Agrarian College of Management and Law Poltava State Agrarian Academy.

\section{EXPOSITION OF BASIC MATERIAL}

In spite of certain problems (financial, skilled, material and technical), it is possible to consider understanding of importance of electronic education great success in practice of agrarian institutes of higher of I-II of levels of accreditation: at first exceptionally as the use of forms of the controlled from distance education, understanding of electronic education as possibilities of considerable perfection of ordinary forms of studies came later. It should be noted that the controlled from distance education in agrarian colleges is in the embryonic state, considering exactly by the problems marked higher.

For this reason it is expedient to embed $R B L$, which foresees development of informatively-educational environment of college by means of modern IKT and webtechnologies. Today under an informatively-educational environment (IEE) understand single informatively-educational space, built by means of integration of information on traditional and electronic transmitters, computer-telecommunication technologies of cooperation, which contains virtual libraries, distributed databases, educational and methodological complex and extended vehicle of didactics, in which principles of the new pedagogical system (Biletska, 2012).

The important stage of integration of the modern informative systems to IEE of agrarian colleges in the context of RBL are creation and introduction of electronic educational resources and e-librarys which support corresponding multidimensional access to units of maintenance, that allows a reader or listener to pick up necessary materials in a sufficient measure.

An e-library in this case comes forward as a center of not only traditional systematic directory but also by the mestome of maintenance of Video Library and Netnews, communicating through deliveries of lists, due to which users which placed the address of e-mail in this list will be able operatively to get information about new receivables (Shahmaev, 2000).

Under an electronic educational resource (EER) understand educational, scientific, informative, reference sources and tools, worked out in an electronic form and presented on transmitters any to the type or placed in computer networks which are recreated by means of electronic digital hardware and needed for effective organization of educational-educator process, in the part regarding to its filling by high-quality educational and methodological materials (Decree, 2012).

Problems with providing of students textbooks, rapid obsolescence of existent textbooks from an informatics and other disciplines of computer cycle, absence of only didactics resource, own desire of students to have educational materials in an electronic form at first induced us to development of electronic textbooks and manuals.

Today the requirements of time transform an electronic textbook (manual) in an electronic educational resource and carry him to the World network, realize the same 
more wide access to him, individual trajectory of studies, interactive socializing with a teacher, common use and creation of its content on the basis of modern webtechnologies and services of the Internet, freedom of choice for a student. Therefore development of valuable EER became the logical, self-weighted and necessary next step in a network the Internet.

It follows to pay attention that EER can contain and electronic textbooks, and computer trainers, and virtual laboratories, and valuable electronic educational and methodological complexes of disciplines, and also tools on-line intercourse and other services of the Internet.

As marks 0 . Spirin, the use of electronic materials is special characteristics, valuable for effective organization of public life: inexhaustibility, high speed of distribution, economy, ecological cleanness, considerable shelf-life at insignificant resource charges and others like that.

Modern tools of working of data and connection are basis of new ICT, which all anymore determine maintenance, scales and rates of development of other technologies (Spirin, 2007, p: 14).

Development of EER, advantage of which is availability of the use, adequacy to the level of development of modern scientific knowledge, providing of individual rate of study of discipline, by the tools of web-technologies, in particular, by the tools of free hosting and their further use allows to decide the next tasks of educational process in a college:

$>$ orientation on the certain category of users, on flexible satisfaction of complete spectrum them informative necessities;

$>$ realization of motivation of students is to the studies and self-training;

$>$ realization of any stage of employment (actualization of knowledge, serve of new material, control of knowledge and others like that) is in the new context of the use of modern web-technologies;

$>$ providing of possibilities of context search and information retrieval activity;

$>$ providing in full modern educational and methodical materials (operation ability of updating of materials);

$>$ the valuable interactive socializing is with a teacher;

$>$ more complete realization of principle of evidentness by tools multimedia (texts, graphic arts, sound, video);

$>$ creation of computer-integrated courses;

$>$ upgrading of electronic tools of studies after the aggregate of parameters : rich in content, technical and technological, didactics, methodical and ergonomic design;

$>$ unity of functionally-technological purpose: collection, accumulation, working, distribution of informative resources of educational purpose;

$>$ cost of educational establishment effectiveness;

$>$ scale of application of the finished good (thousands-millions of users);

$>$ access to the digital scientific and educational and methodical resources of e-librarys: electronic in-informative resources of educational environment of the open pedagogical systems, and also working of these resources with the aim of preparation, classification and high-quality analysis of electronic documents and editions; 
$>$ an orientation is on informatively-technological support of educational activity in industry of leading divisions of science and practice, on application of innovative tools of studies and pedagogical technologies;

$>$ forming of open educational environment.

The use of EER will give to the participants of educational-educator process of college of possibility to get necessary knowledge, freely using practically unlimited on a volume informative resources, modern ICT and web-services.

Informative resources are databases and knowledge, computer, including multimedia, systems of educational purpose, video- and audio records, e-librarys, together with traditional textbooks and methodical manuals, form the informatively-resource providing of open education, accessible to the wide audience of users.

With the aim of decision of question of correlation of the controlled from distance and traditional studies, not contrasting modern electronic tools and technologies of studies to the traditional forms, and organically complementing them to the uses in an educational process, carrying out on this basis effective organization of independent work of students in the Agrarian College Of Management And Law Poltava State Agrarian Academy the electronic educational resource of "Information+": was worked out http://informatika-resurs.jimdo.com (Figure: 1).

The Electronic educational resource of "Information +" combines in itself all descriptions and principles of creation of electronic textbooks and other electronic tools of educational purpose and is a modern didactics resource for the study of disciplines of computer cycle, which are laid out in a college.

This resource is run-time, has the specialized integration of functional possibilities; new components of software can easily be plugged in a depository for their next use and executes the basic task - integration of informative resources and effective navigation for them.

An important factor which influences on success of introduction of similar informative resources is methodological approach of the systems to their planning and realization. Such approach the use of CASE of-technology is the basis of, which allow to execute the design of the informative system on all phases of her development: on the stage of structural analysis, global planning and realization (Zavyalova, 2001).

The EER of "Iнформатика+="Information+" is created by means of designer of sites of Jimdo, which does possible creation of sites simply (does not require the special abilities and knowledge as if programming), quickly and, mainly, free of charge, that it is especially important, taking into account the modern state of the financial providing of agrarian colleges.

A modern open environment of EER of "Information+" is potentially unlimited in relation to the volumes of resources, which can be applied in an educational-educator process, quantity of users which can use its tools and technologies, and that is why and amounts of students, which can be jointly brought over to uniting of only didactics task. In such environment additional are created for realization of different aims, strategies and trajectories of studies and education of student as a future specialist, for providing of adaptation of components of EER to individual possibilities and necessities of students. 


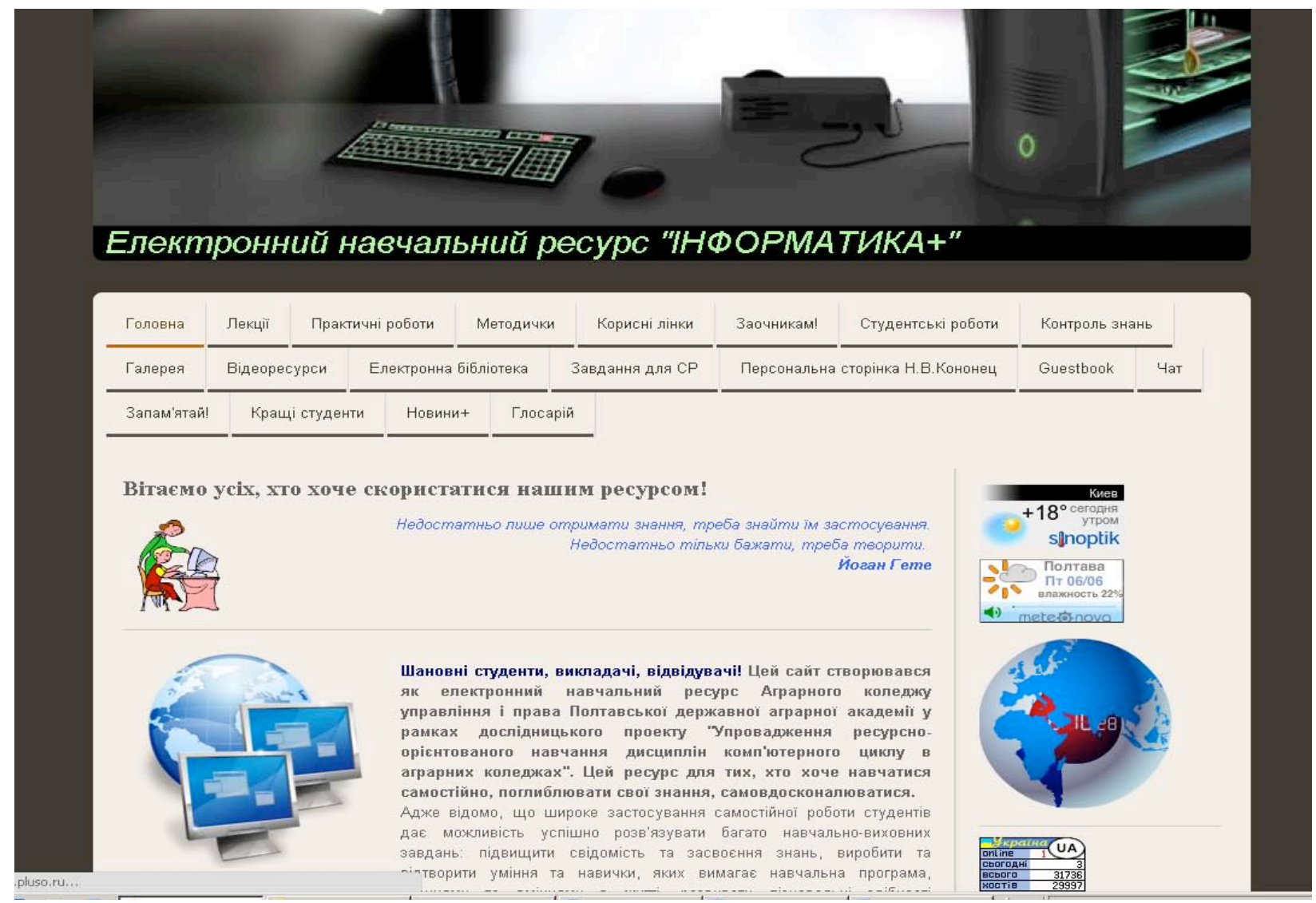

Figure: 1

EER of "Information+"

In other words, EER on the whole substantially enriches didactics possibilities of the pedagogical systems, strengthens them didactics descriptions which are the indisputable positive sign of open educational environment.

For successful introduction of RBL of disciplines of computer cycle we used services of Google and worked out the Cloudy resource from disciplines of computer cycle (Figure: 2). A cloudy resource shows by itself aggregate of electronic educational and methodical complexes of such disciplines of "Computer Science and Computer Engineering", "Electronic commerce", "Data Protection", "Computer technologies in legal activity" and other the Cloudy resource contains videolectures, tests and mediafolder. 


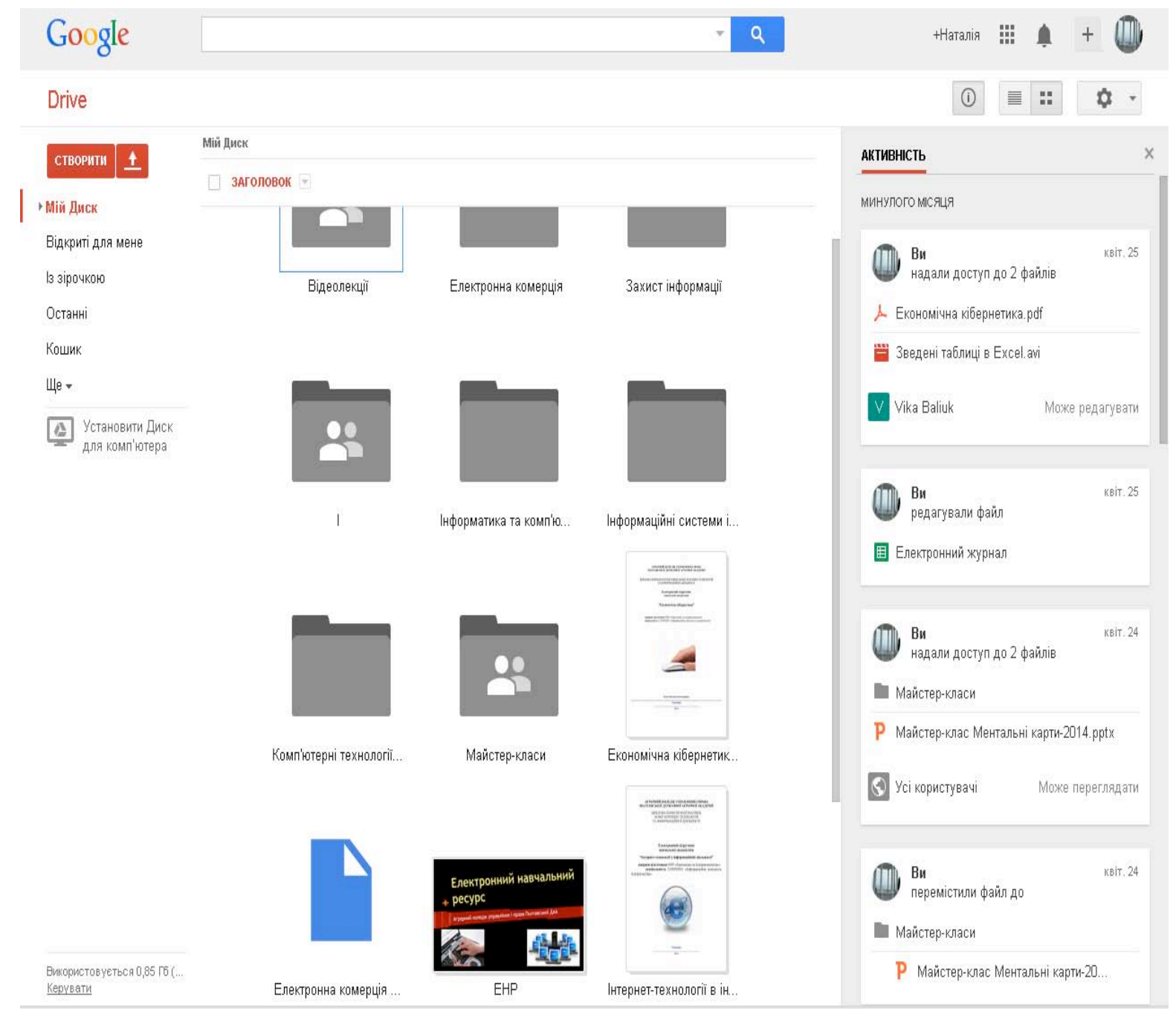

Figure: 2

A cloudy resource is from disciplines of computer cycle

An alternative to full distance learning is to organize online learning with the use of electronic content-developing electronic courses distance learning opportunities (registration, obtaining temporary access to educational resources, virtual classes, monitoring progress, etc.). Based on free hosting type uCoz, sites.google.com.

Services of Google enabled organization on-line of studies. In Agrarian College Of Management And Law Poltava State Agrarian Academy we organized two such the sites on electronic educational content "IT-освіта" http://baliuk.ucoz.ua (Figure: 3).

It is sites for the study of disciplines "Economic cybernetics" and "Internet technologies in informative activity" (Figure: 4). 


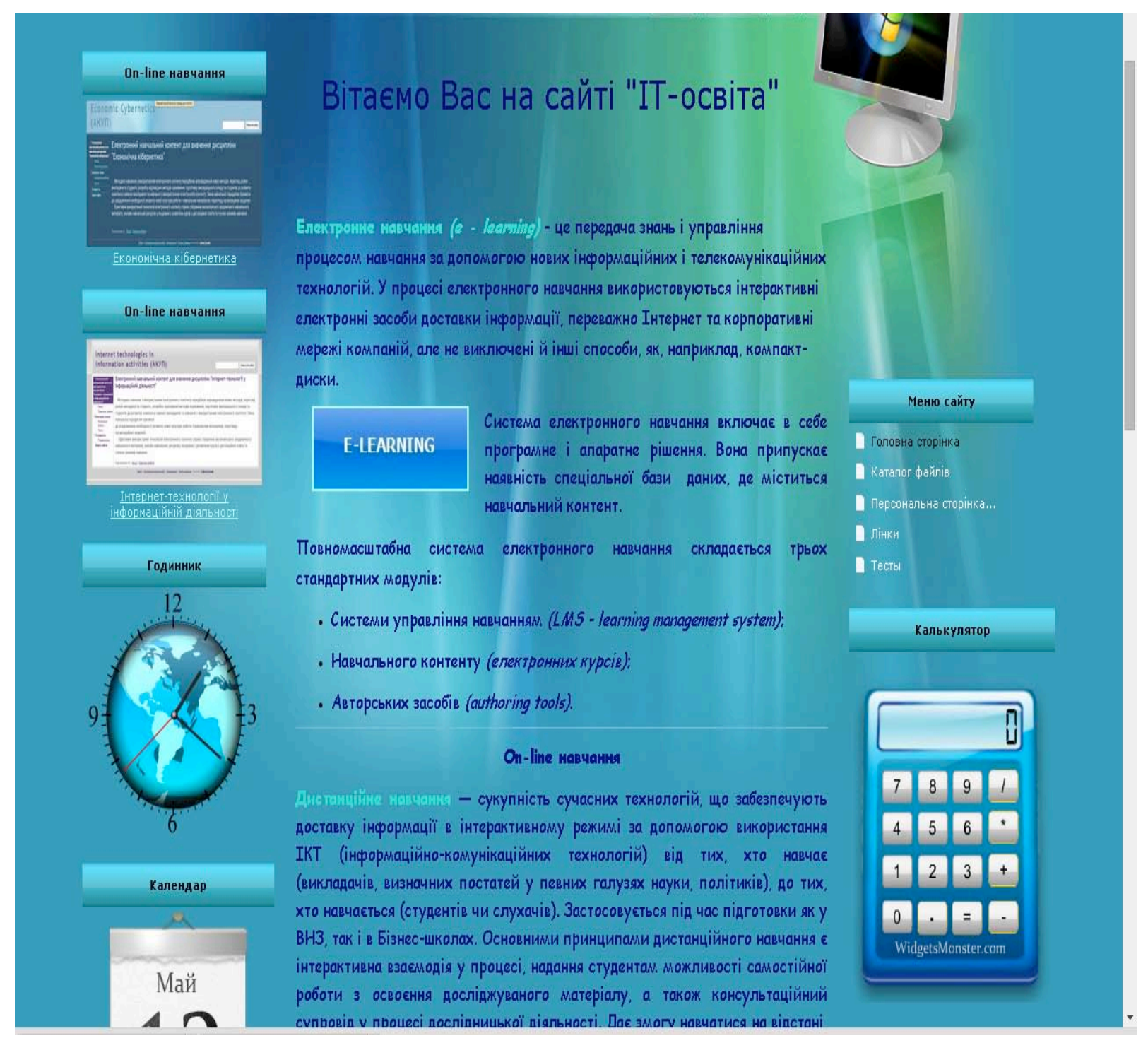

Figure: 3

Electronic educational content is "IT-education"

On a site on-line study it is needed to be registered. Registration is actual in a period the study of discipline. A site contains electronic educational materials and electronic magazine of success. 


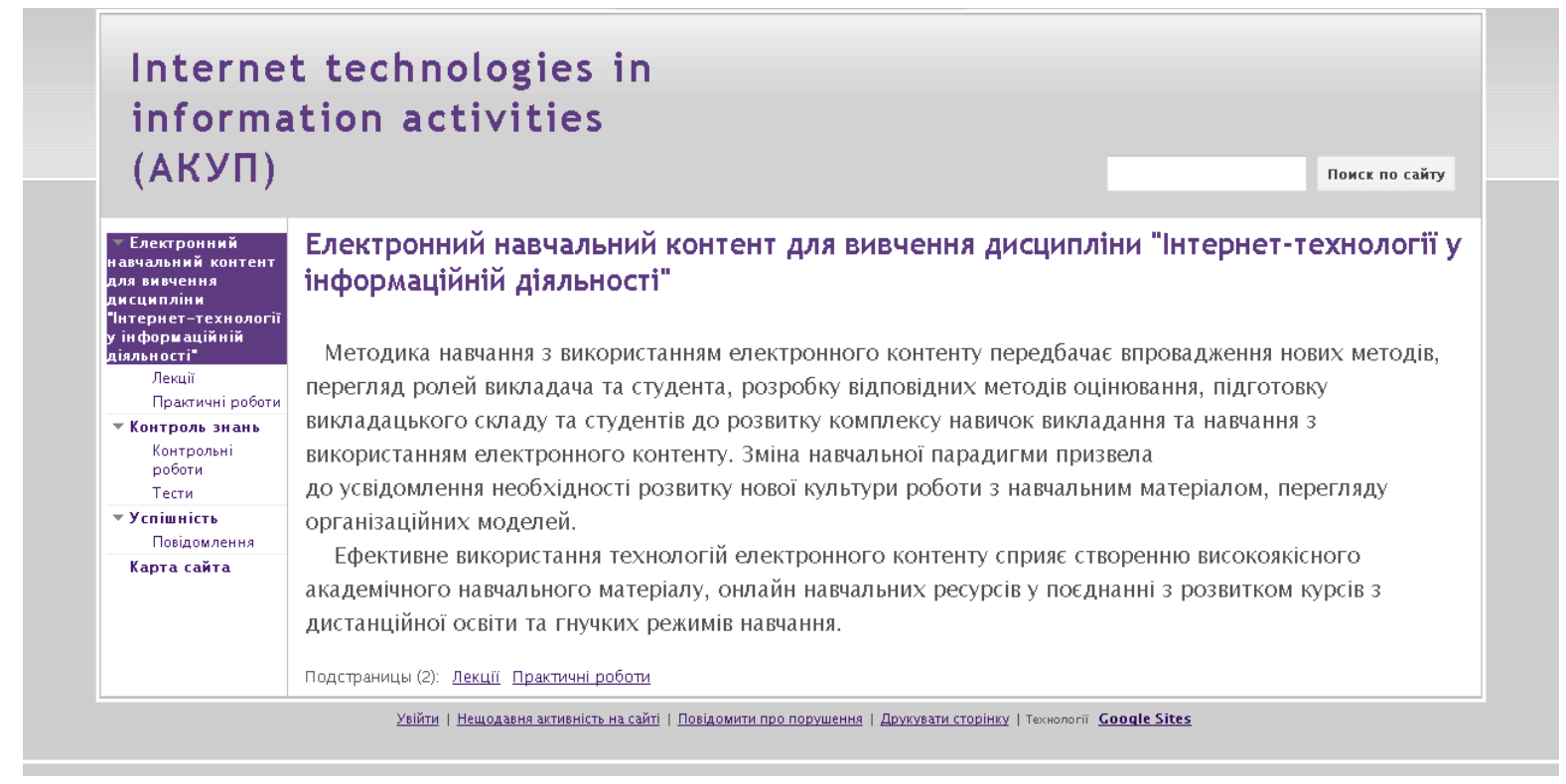

Figure: 4

A site of study of course of "Internet technology is in informative activity"

Familiarizing with electronic educational resources is possible on a site the Resourcebased learning: methodical portal of http://rbl3.webnode.com.ua (Figure: 5).

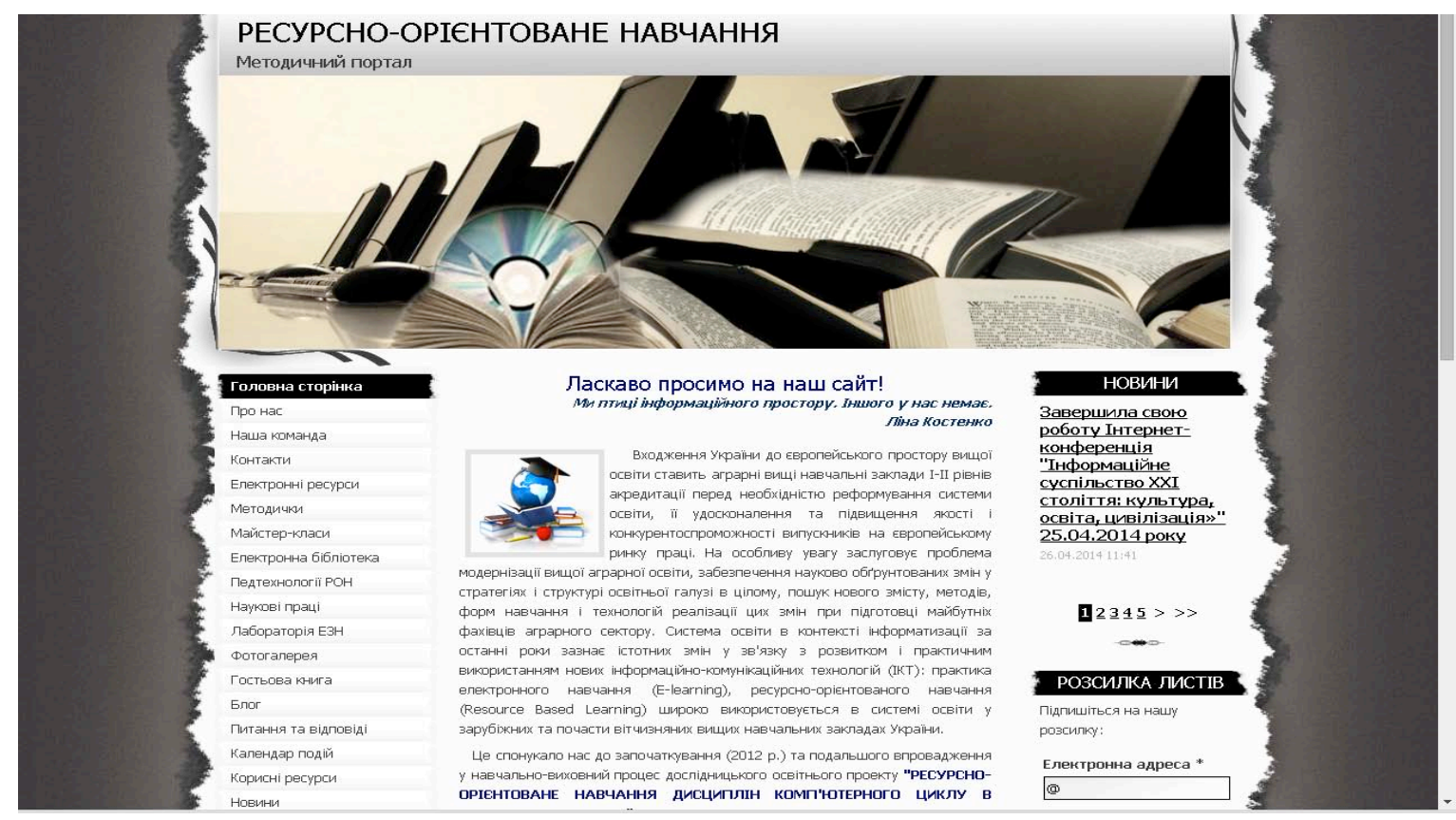

Figure: 5

A site is the Resource-based learning: methodical portal

RBL of disciplines of computer cycle, oriented on the use of such EER, allows to realize all principles of modern didactics and next possibilities : openness and availability of 
studies, overcoming of physical limitations of man, expansion of audience of students; individual orientation of studies, creation of comfort terms for students and teachers, account of individual psychological features (perception, memory, thought), individual rate of studies; development of informative culture and competence, skills of work is with the modern tools of I CT and web-services; socialization of studies, account of personality-communicative features of students.

It should be noted that today the basic criterion of efficiency of the use of new information technologies in an agrarian college is already a not presence the determined amount of computers, but creation of only IEE.

Every Agrarian College must have a collective which owns an informative culture and information technologies of studies. Creation of IEE of college provides:

$>$ continuous education (the dynamics of development of modern technologies requires for support to qualification continuously to promote the professional level of workers);

$>$ open education (high availability of education is needed for satisfaction of growing necessities of society in specialists and achievement of success of individual in the modern world);

$>$ assured result of studies (a graduating student must have the assured level of general and professional competences, readiness to practical activity without additional studies in the workplace, willingness to perceive and seize new technologies during all term of professional activity) (Yarem, 2013).

The use of Internet technologies does possible creation of IEE exactly due to development and placing of E ER in the World Wide Web, as a network the Internet extends his possibilities, services, information which is meaningful from the point of view of education placed with her help constantly.

The internet is multifunction - next to functions searching (directories, collections of references, strategy of search in the searching systems) and informative (e-libraries, virtual centers, databases, e-books and magazines, methodical literature), he performs the interactive duty, that allows students and teachers to communicate by means of email, forums and on the personal chats, SKYPE and ICQ, and also to arrange videoconferences.

The substantial line of electronic pedagogical activity is her orientation on education of students, which is based on organization of cognitive activity in individual and collective forms as activity self-education; system diagnostics of the personal internals of student and support of him individual increase; use of possibilities of IEE.

A meaningful factor for achievement of high-quality results is a level of organization of pedagogical process by a network teacher. To our opinion, using for RBL of such tools, as EER is useful, as allows untying the row of tasks:

$>$ providing of availability of various educational resources;

$>$ a receipt of universal and professional education is in a comfortable, adequate and corresponding form for a student;

$>$ importance for psychological development of student in modern terms - its bringing in systematic educational activity under direct guidance of 
teacher, process of possessing a culture and socialization pass by means of teacher;

$>$ developing creative and intellectual flairs of student by means of the open and free use of all educational resources and programs, including, accessible in the Internet;

$>$ exchange of data, communicative activity on the base of general interests, foremost professional and educational;

$>$ an assistance to development of the controlled from distance education is in a college;

$>$ organization of leisure, rest and development;

$>$ an exchange of creation and general use of various educational resources experience is in all agrarian colleges of Ukraine;

$>$ in-plant training, retraining or change of professional activity.

\section{CONCLUSIONS}

The problem of upgrading of preparation of students, optimization, intensification of process of studies and individualization of studies of students of agrarian colleges will do possible to decide the modern going near organization of educational process are the resource-oriented studies, and also ICT of educational purpose, which electronic educational resources which provide achievement of pedagogical and didactics aims are, no doubt, as with the use of ICT and web-technologies of possibility of organization of individual work of students and her quality broaden considerably.

RBL called to help in global educational space, it comes forward as effective integrative combination of traditional and innovative forms of education, as a tool of partial decision it urgent problems, in particular, gives possibility simultaneously with flexible at times and by the high-professional on maintenance study of different subject divisions of knowledge, forming of abilities and skills of work from many educational disciplines to provide intensive practical application those, who study, by methods and tools of informatively-communication technologies, develops ability and skills in modern science and practice.

Introduction of RBL in agrarian colleges is a necessary condition for achievement of modern level of quality of agrarian education.

The conducted research does not dip out all aspects of introduction of the resourceoriented studies of disciplines of computer cycle in agrarian colleges and in further requires integral, system consideration and analysis of tools, methods and methods of its organization.

\section{BIODATA and CONTACT ADDRESSES of the AUTHOR}

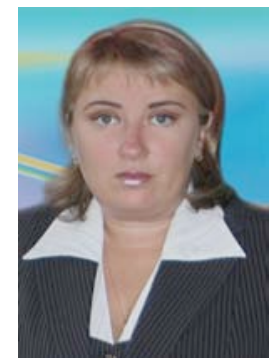

Natalia KONONETS, Ph.D., teacher of the highest category, teachertrainer, teacher of computer science and computer technology, Agrarian College of Management and Law Poltava State Agrarian Academy. Ph.D. in the field of "Learning theory". Lecturer in master classes at the State Institution "Scientific-methodical centre of information and analytical support for higher education institutions "Agroosvita", member of the scientific-methodical commission on "Implementation of information systems and technologies in the activities of higher educational institutions of Ukraine". Labour has opposed the Ministry of Agrarian 
Policy and Food of Ukraine "Badge of Honour". Is working to develop e-learning, teaching methods disciplines of computer cycle, teaching the basics of resource-based learning cycle students of computer sciences Agrarian Colleges. Author of more than 75 scientific papers on Educational Sciences: didactics, information technology in education.

Natalia KONONETS, Ph.D., professor of computer science and computer technology Agrarian College of Management and Law Poltava State Agrarian Academy UKRAINE, 36034, Poltava, st. Primakov, 12-a, kv.47

Tel.: +38-066-12-12-741

Email: natalka_poltava@mail.ru

\section{REFERENCES}

Білецька Г. А. Сучасні інформаційні освітні середовища та їх застосування у професійній екологічній освіті / Г. А. Білецька // Педагогіка формування творчої особистості у вищій і загальноосвітній школах : 36. наук. пр. - Запоріжжя, 2012. Вип. 22 (75). - С. 74-81. [Biletska, G.A. (2012). New information educational environment and their application in professional environmental education / G.A. Biletska // Pedagogy forming a creative personality in higher and secondary schools: Coll. sciences. etc. - Zaporozhye, 2012. - Vol. 22 (75). - P. 74-81.]

Завьялова Н. Б. Методология разработки интегрированной информационной образовательной среды / Н. Б. Завьялова, Л. П. Дьяконова // Материалы: XI конференция-выставка «Информационные технологии в образовании» - М., 2001 200 c. [Zavyalova, N.B. (2001). The methodology for developing an integrated information educational environment / N.B. Zavyalova L.P. Dyakonova // Materials: XI Conference and Exhibition "Information Technologies in Education" - M., 2001 - 200 p.]

Кононец Н. В. Педагогічні інновації вищої школи: ресурсно-орієнтоване навчання / Наталія Кононец // Педагогічні науки : 36. наук. праць. - Полтава, 2012.- Вип. 54.C. 76-80. [Kononets, N.V. (2012). Pedagogical innovations higher education: resourcebased learning / Natalia Kononets // Teaching Science: Coll. sciences. works. - Poltava, 2012. - Vol. 54. - P. 76-80.]

Наказ № 1060 від 01.10.2012 Міністерства освіти і науки, молоді та спорту України "Про затвердження Положення про електронні освітні ресурси" [Електронний ресурс] / Верховна Рада України. - Режим доступу: http://zakon4.rada.gov.ua/laws/show/z1695-12 [Decree (2012) № 1060 of 01.10.2012 of the Ministry of Education, Youth and Sports of Ukraine "On Approval of the electronic educational resources" [Electronic resource] / Parliament of Ukraine. - From: http://zakon4.rada.gov.ua/laws/show/z1695-12 ]

Спірін О.М. Теоретичні та методичні засади професійної підготовки майбутніх учителів інформатики за кредитно-модульною системою : монографія / О.М. Спірін. - Житомир : 2007. - 300 с. [Spirin, 0. (2007). Theoretical and methodological foundations of professional training of teachers for science credit system: monograph / O. Spirin. - Exactly: 2007. - 300 p.]

Шахмаев Н.М. Технические средства дистанционного обучения. М., 2000. - 276 с. [Shahmaev, N.M. (2000). Technical means of distance learning. M., 2000. - 276 p.] 
Ярем О. А. Електронний журнал, або в ногу з часом [Електронний ресурс]. / О. А. Ярем. - Режим доступу: -

http://www.rusnauka.com/4_SND_2013/Pedagogica/5_125943.doc.htm [Yarem, O.A. (2013). Electronic journals, or up to date [Electronic resource]. / O.A. Yarem. - From:

http://www.rusnauka.com/4_SND_2013/Pedagogica/5_125943.doc.htm ]

Bologna and the challenges of e-Learning and distance education, Gent. Belgium, 4-5 June 2004.

Hadjerrouit, S. (2005). Web-based educational software in computer science: Technical and pedagogical usability. Proceedings of ED-MEDIA 2005, 1139-1144.

Hadjerrouit, S. (2010). A conceptual framework for using and evaluating Web-based learning resources in school education. Journal of Information Technology Education, 9, 53-79.

Holt, D., Rice, M. and Armatas, C. (2002), Issues arising from an online resource-based learning approach in first year psychology, in Winds of change in the sea of learning: proceedings of the 19th annual conference of the Australian Society for Computers in Learning in Tertiary Education (ASCILITE), UNITEC Institute of Technology, Auckland, New Zealand, pp. 287-297. 